\title{
Transformation of Panglima Laot in Aceh: From Punggawa to Customary Institution
}

\author{
Mahendra Pudji Utama*, Yety Rochwulaningsih, Singgih Tri Sulistiyono, and \\ Mujiburrahman \\ Departement of History, Faculty of Humanities, Diponegoro University, Semarang, Indonesia.
}

\begin{abstract}
This paper discusses how Panglima Laot transformed into the republic from kingdom era. During the kingdom era, Panglima Laot had an important role in the maritime sector, particularly in collecting vessel excise. However, during the Dutch Colonial military penetration, Panglima Laot had adapted to the war situation. After the independence, it adapted to the different situation where kingdoms were no longer exist. This political change transformed Panglima Laot in terms of function, value and position as a form of adaptation. This study uses historical method, especially analyzing local as well as the colonial sources. It also included journal as the reference. This study shows that Panglima Laot gradually transformed based on certain phase. During the war phase, Panglima Laot transformed into the war force to face the Dutch military penetration. After the independence, Panglima Laot had to adapt once again, it transforms into a customary institution serving for the fishermen within the traditional corridor. Panglima Laot eventually becomes the maritime culture of the Kingdom of Aceh for Indonesia. The existence of Panglima Laot as a customary institution managing the coastal area is recognized by the Country in the law.
\end{abstract}

Keywords: Panglima Laot; Transformation; Kingdom of Aceh; Indonesian Republic.

\section{Introduction}

As a maritime country, Indonesia has a long history and diverse maritime cultural heritage. This diversity is a unique wealth of treasure for Indonesian. One of the uniqueness of the vast maritime cultural heritage of Indonesia is Panglima Laot. Panglima Laot is maritime cultural heritage from the Kingdom of Aceh that still exists as a local wisdom of coastal area in Aceh. As we know that during the past centuries after the fall of Srivijaya, Aceh became one of the strongest maritime kingdoms in South East Asia specifically after the Malacca Kingdom in Malay Peninsula was occupied by Portuguese in 1511. As a maritime kingdom, Aceh universally has values rich in maritime culture, from the governance system, economics to

* Corresponding author: maheutama@live.undip.ac.id 
the community livelihood system. Panglima Laot is an evidence and reflection that the Kingdom of Aceh is a maritime kingdom.

According to Adli Abdullah, Panglima Laot has been existed since the era of Samudra Pasai Kingdom in the 14th century, and enforced by Sultan Iskandar Muda (1607-1636). At that time, the position of Panglima Laot was the extension of the sultan in performing two main responsibilities, that were collecting excise from the trade vessels docked at the harbor and mobilizing the people for the sake of war [1] According to C. van Vollenhoven, Panglima Laot has been one of the official institute regulated by the government [2]. The same opinion is also suggested by A.M. Djuliati Suroyo that Aceh, during Sultan Iskandar Muda issued the customary law of the sea which specifically regulated fishing at the sea, related to fishermen, wages, boats, equipment etc. The official dealing with this matter is Panglima Laot [3].

The opinion above shows that Panglima Laot is an institution established since the Kingdom of Aceh and has important roles in maritime sector. However, along the history of Aceh, the values and even position as a significant institution managing the sea sector of Panglima Laot has been shifted. It is undeniable that many factors have caused the shifting of value and position of Panglima Laot in the maritime sector of Aceh. The shift was mainly due to the long course of war between Aceh and the Dutch. According to Ibrahim Alfian, Aceh-Dutch was an overly lavish war. He even asserts that Aceh-Dutch war was the longest and most expensive colonial war [4]. The same opinion is also stated by Majid, that Aceh and Dutch war were not only long and costly, but also the greatest war of the Dutch in Indonesia [5].

The impact of colonial war in military aspect had destroyed all the value order system in the Kingdom of Aceh. This great conflict induced a huge impact, including for Panglima Laot itself. One of the biggest impacts due to Aceh-Dutch war in cultural and maritime sector in Aceh was adaptation. The adaptation occurred to deal with the penetration and domination of the Dutch colonial force after the expansion of the Dutch to Aceh since the 19th century. This adaptation process led to the transformation of Panglima Laot, both in value and position.

The transformation of Panglima Laot did not occur during Aceh-Dutch conflict only, but also when the republic was formed. During the independence phase, Panglima Laot had changed its values and position. This change was the result of the cultural adaptation itself to the existing situation and condition. Hence, this paper attempted to answer how the transformation process of the function and position of Panglima Laot since the Kingdom of Aceh due to local adaptation during the Dutch colonial penetration until the Republic of Indonesia was established.

\section{Method}

The article is using the historical method, the operational step in this research is collecting various sources regarding commander laot, ranging from local sources and colonial sources to the contemporary sources. In addition, this articles also use secondary sources that are relevant to the topic, such as books and journals.

\section{Results and Discussion}

\subsection{Panglima Laot during the kingdom era}

As mentioned earlier in the background, Panglima Laot has been existed since the kingdom era. Panglima Laot had important roles in maritime management of Aceh during the kingdom era. There is indeed a few of sources that can be used as a reference to show that Panglima 
Laot was included in the structure of the Kingdom of Aceh. The sources, however, stated that Panglima Laot was an institution managing the maritime sector which was directly under the ministry of transportation. Therefore, it can be said that Panglima Laot had strategic roles in a maritime-visioned kingdom.

Panglima Laot bore vital responsibilities during the kingdom era. Panglima Laot was the extension of the sultan in performing two main responsibilities, that were collecting excise from trade vessels docking at the harbor and mobilizing the people for the sake of war. From those tasks, it can be interpreted that Panglima Laot had a strategic position in managing the sea of Aceh. Iskandar Muda was the renowned king of Aceh. The period of his leadership can be used as an important stepping stone in studying the development of the Kingdom of Aceh. The gait of Panglima Laot during the kingdom era can be seen at this phase. During the period of Iskandar Muda, the structure of Panglima Laot was not clearly written in the structure of the kingdom. Nevertheless, many historians believe that Panglima Laot had played an important role during the reign of Iskandar Muda. If referring to the structure of kingdom during Iskandar Muda, Panglima Laot did not have a clear position. One of the remarkable strategies of Iskandar Muda was the concept of structural governance system. Therefore, in the governance sector, Sultan Iskandar Muda had formed some governance units [6]. In carrying out and controlling the government, Iskandar Muda was assisted by royal assistants structured in the kingdom structure. The highest level of the structure in the Kingdom of Aceh was the central government, located at the center of the kingdom in Banda Aceh Bandar As Salam. The head of central government was the sultan who had the title of Sultan Iskandar Muda. He was assisted by 24 assistants or ministers [7]. The followings are the number of ministers under Sultan Iskandar Muda:

1). Keurukan Katibul Muluk or Secretary 2). Rais waizrat Addaullah or Prime Minister 3). Wazirat Addaulah or Minister of State 4). Wazirat al Akdham or Grand Minister 5). Wazirat al Garbiyyah or Minister of War 6). Wazirat al Haqqamiyah or Minister of Law 7). Wazirat ad daraham or Minister of Finance 8). Wazirat ad mizan or Minister of Justice 9). Wazirat ad maarif or Minister for Foreign Affairs 10). Wazirat al Kharijjiyah or Minister for Home Affairs 11). Wazirat al Addakhilyyah or Minsiter for Home Affairs12). Wazirat al Auqat' or Minister for Waqf Affairs 13). Wazirat al Azziraah or Minister of Agriculture 14). Wazirat al Maliyyah or Minister of Property 15). Wazirat al Muwashalat or Minister of Transportation 16) Wazirat Asighal or Minister of Work Affairs 17). As Syaikh al Islam Mufti four syeikh Kaabah 18). Qadli al Malik Adil or Qadi or the just king19). Wazir Tahakkum Muharrijlailan or Chief Coordinator of Art Corps 20). Qadli Muadhlam or Qadi/Attorney General 21). Imam Bandar Darul Makmur Darussalam22). Keucik Muluk or Keucik Raja 23) Imam Muluk or Imam Raja 24). Panglima Khaduri Muluk or Chief Executive for King Khanduri.

In the structure of kingdom contained in qanun meukuta alam, Panglima Laot is not explicitly stated in the structure of kingdom. Therefore, it can be concluded that Panglima Laot is not a ministerial position in the kingdom. Yet, other source explains how the position and requirements for Panglima Laot during the kingdom era. It can be found in the book of tsabakat tsakirat. The book clearly states that Panglima Laot is not a minister. It is a position under the minister of transportation. Based on the manuscript of Tazkirat Tsabakat copy of Tgk in mulek in $1270 \mathrm{H}$, it calls Panglima Laot as amirul albahri. Here is the excerpt of Panglima Laot in tzakirat tsabakat:

Amirul albahri is panglima laot as well as kejruen kuala, complying with the minister of transportation as the first requirement, can be assigned to panglima laot dan kejrun kuala; then both of them have the same requirement as gechik; obligatory to 20 points of requirement. 
Based on the description of tzakirat tzabakat, panglim laot was not a minister, but under the minister. Panglima Laot was under the minister of transportation, where the maritime issues were under the minister. In the governmental order of the Kingdom of Aceh, it had ministers as the assistants of the sultan. According to Rusdi, sultan had 24 helpers or ministers [7].

From the explanation above, it shows that Panglima Laot is an important division in the Kingdom of Aceh that deals with maritime under the minister of transportation. During the conflict or war, Panglima Laot has its own roles in mobilizing the people for the sake of the war.

\subsection{Panglima Laot during colonial penetration}

Aceh-Dutch war was a long and exhausting war. Beside the great death toll, Aceh-Dutch war also consumed a lot of money for the war. Both Aceh and the Dutch suffered from material and non-material loses. Based on the value order, the cultural aspect of government system was damaged due to the war. Therefore, the local values in Aceh had to adapt as the consequences of the prolonged war.

Panglima Laot which was a part of Acehnese maritime management received the impact of the colonial penetration to Aceh. Moreover, Aceh-Dutch war positioned the sea as an important media. It could be seen from the war policy by the colonial such as sea and harbor blockage. It was an evidence that this war was dominated by naval warfare. Therefore, Panglima Laot as the courtier of the kingdom was involved in the war against the Dutch. Aceh war was a civil war involving all element of the society. Lieutenant General T. Van Zijll De Jong who was an Army Commander and the Head of Dutch East Indies War Department stated that in the art of war, if all men-women residents and children even though they were inactive, they took the passive roles against the enemy, then such war was called as a civil war [4]. This opinion is an illustration of Aceh-Dutch war. Therefore, it also supported that Panglima Laot was part of Kingdom of Aceh's force against the Dutch. One example that sea was strategic in the conflict between Aceh-Dutch was the effort of Aceh in preparing to face attacks from the Dutch. Since August 1872 to March 1873, Aceh loaded 5000 barrel of gunpowder caskets and 1349 chests of rifle from Pinang Island. [4] The loading process of the war equipment was definitely by sea, where there would be the role of the royal sea courtier in supplying weapons. Although after that the British Colonial government in Singapore on March 31, 1873 issued a law banning the export of weapons and gunpowder from any place and port in the British Colony environment to Aceh [5].

Indeed, it should be recognized that the record regarding Panglima Laot in the conflict of Aceh-Dutch is almost unavailable. Only a few Dutch Colonial newspapers wrote about the roles of Panglima Laot in the long conflict between Aceh and the Dutch. From this colonial source, it was proved that Panglima Laot had a great role in Aceh war. Even though the role was not recorded well in manuscripts. One of the Acehnese fighters who was well known to the colonial was Teuku Umar. Umar himself was actually a Panglima Laot, with the title amirul albahri as explained by Tsakirat Tsabakat masnuscript.

The rigors of Aceh-Dutch war had claimed many lives, both on the side of Aceh and the Dutch. The Dutch even lost many of its soldiers, even the general died in Aceh. While Aceh lost many fighters, including the king due to cholera. Paul van'T Veer revealed that the death of the sultan due to cholera did not affect the Acehnese resistance against the Dutch at all. [8] Responding to the situation at that time by adhering to the customary law, the Acehnese figures enthroned Tuanku Muhammad Daud Syah as the Sultan located at the Indrapuri mosque in 1878. Because during the coronation as the Sultan of Aceh, Tuanku Muhammad Daud Syah was still young, the government was run by Tuanku Hasyim, a religious person, as a mangkubumi [4]. In late 1883, Tuanku Muhammad Daud Syah was considered an adult 
and ready to bear his duties as a sultan, and his existence was recognized as a sultan by the Acehnese people [4]. In addition, an amirulbahri or Panglima Laot was also appointed for West Aceh region, and the one who was appointed at that time was Teuku Umar [9]. While Tuanku Mahmud Bangta Kecil, Tuanku Hasyim Bangta Muda's younger brother, was appointed as the deputy of Sultan. The appointment of Teuku Umar as Panglima Laot for West Aceh is a great indication that Panglima Laot played a strategic role in the Dutch-Aceh war. According to Hurgronje, Teuku Umar spent a lot of time in the West Coast region [10].

Aside from Teuku Umar, there was another Panglima Laot who gave significant pressure and resistance against the Dutch. One of them was Panglima Laot Ali, not many records were found regarding him. Panglima Laot Ali was the leader of the troops from Cut Nyak Dhien group which was the widow of Teuku Umar. Becoming the warlord of Cut Nyak Dhien was definitely a bloody war on the battlefield, and he tore the Dutch kaphe's chest with rencong (traditional weapon from Aceh) until he lost his life. This means that his existence as Panglima Laot showed that he was the vanguard against the Dutch. Other than the vanguard, it was impossible to lead the troops with Cut Nyak Dhien within it. As it was known that Cut Nyak Dhien was an Acehnese woman whose bravery was taken into account by the Dutch. Panglima Laot Ali was known as the commander of the troops because he was the one who handed Cut Nyak Dhien to the Dutch. Cut Nyak Dhien was arrested by Lieutenant Van Vuuren on November 4, 1905. This arrest happened due to the instruction of Panglima Laot Ali. It was because he could not bear to see Cut Nyak Dhien suffered. For eight days Cut Nyak Dhien did not eat and lived only on roasted bananas and banana stems, while she was also blind. When Cut Nyak Dhien found out that she was handed over by her commander, she was furious. She even took out her rencong, about to stab her commander who was considered as a traitor and subjected to the Dutch kaphe [8]. The Dutch sentenced Tjoet Njak Dèn as a city prisoner in Kota Radja for the sake of peace and public order (rust en orde) [11]. Based on the Dutch Newspaper issuance of 3-01-1942, it was retold that what the trusted Panglima Laot of Teuku Umar had done to Cut Nyak Dhien who was also the commander of his troops was out of compassion for the suffering of Cut Dhien. Van Vuuren said that there was the legendary Panglima Laot with Cut Nyak Dhien. He was the oldest confidant of Toekoe Oemar. For 24 hours, Panglima Laot marched from the Kota Bahroe and asked the lieutenant to come to him without armed. Van Vuuren considered it carefully, but he decided to leave anyway [12]. Panglima Laot during the colonial penetration had been transformed into part of Aceh's force in facing the Dutch Colonial military forces.

\subsection{Panglima Laot during independence}

After the independence, it was a new round for the history of Panglima Laot. In this phase, the adaptation of Panglima Laot was also great. The transformation through adaptation was mainly due to the fact that the kingdom was no longer existed. Its position and function were different, but its existence still exists until today. However, there has been a shift in its value, function and position.

In the era of independence, Panglima Laot had become a local wisdom in the coastal area, a maritime wisdom inherited from the kingdom of Aceh. The local wisdom of Panglima Laot as a customary institution is the maritime cultural heritage of Indonesia from the Kingdom of Aceh, where it is one of the rich treasures of national culture as a maritime country [13]. Panglima Laot was no longer taking care of excise (wase), but totally taking care of fishing activities.

In the era of independence, there were at least four main tasks of Panglima Laot. Below are the tasks of Panglima Laot: 1. To oversee and maintain the customary law of the sea. 2 . To set fishing procedures. 3. To settle various disputes that occur in connection with fishing in the sea. 4. To organize traditional sea ceremonies, handle accidents at sea, mutual 
cooperation and other social problems [13]. Panglima Laot as a local wisdom of Aceh coast is very strategic in regulating all the behavior of the fishermen, as the people who depend their lives on the sea [14]. Each Panglima Laot has a working area in each kuala, where the kuala becomes a fishing ground for the fishermen. Panglima Laot is commonly referred to as Panglima Laot Lhok, while Panglima Laot for District works in accordance with the district area, to Provincial Panglima Laot which includes the provincial work area as well [15].

The explanation above shows that Panglima Laot has been transformed into a customary institution managing the fishermen on the coast of Aceh. Therefore, Panglima Laot is an institution that leads the customs, habits applicable in fishing sector, and dispute resolution in Aceh Province [16]. Nowadays, the existence of Panglima Laot as an institution in Aceh, aside from being a social leader of the community of customary law of the sea, it also becomes a solution to the fishermen's dispute [17]. The fishing dispute resolution is resolved by Panglima Laot through Laot Customary Court [18].

In1990, it was a new round for the existence of Panglima Laot in Aceh after the independence. In this year, the government issued Law No. 2 of 1990 on the fostering and development of customs, habits of the community and the customary institutions of Aceh in the Aceh Special Province recognizing Panglima Laot as a customary institution. In article 1 letter (m), it is stated that Panglima Laot is the person who leads customs, habits that apply in fishing aspect at the sea [19]. This regulation has given a space to Panglima Laot as a customary institution recognized by the State, through local regulations. Where after the issuance of Local Regulation No 2 of 1990, it is also followed by a new regulation regarding Panglima Laot, which is Local Regulation Number 7 of 2000. Provincial Regulation of the Special Province of Aceh, Number 7 of 2000 on the implementation of traditional life. This regulation states that Panglima Laot is the person who leads the customs and habits applicable in fishing sector at the sea including regulating the fishing spot/area, and dispute resolution [20]. In 2006, the government recognized this institution in the Law No. 11 of 2006 on Aceh government [21].

\section{Conclusion}

Panglima Laot was an institution under the minister of transportation during the Kingdom of Aceh. This institution was an extension of the king in terms of excise quotation. In addition to quoting excise, this institution also had a role in mobilizing the people for the sake of war. In the book of tsakir tsabakat, there were at least twenty requirements to be a Panglima Laot during the kingdom era. These requirements also applied to the position of mukim (part of the subdistrict, and consists of several villages) and other positions. During the colonial penetration phase, Panglima Laot functioned and transformed into one of the royal forces against the Dutch, both in warfare and supplying logistics for war purposes. An example of the concrete role of Panglima Laot in the Aceh-Dutch war was the appointment of Teuku Umar as a Panglima Laot (amirul albahri). Besides Teuku Umar, there was Panglima Laot Ali who was the part of Cut Nyak Dhien's troops. While in the independence phase, Panglima Laot was transformed into a customary institution managing fishermen within the corridors of customary law. Then, Panglima Laot became a treasure of the coast of Aceh which was a maritime cultural heritage of the Kingdom of Aceh. In 2006, Panglima Laot was recognized as a customary institution by the State through law. 


\section{Acknowledgment}

This article is funded by Directorate DRPM DIKTI 2019 under the research Doctoral Dissertation Program entitled Penetrasi kolonial dan adaptasi lokal: Perkembangan aktifitas kemaritiman Aceh pada pergantian abad XX.

\section{References}

[1] M. Adli Abdullah, Selama kearifan adalah kekayaan: eksistensi panglima laot di Aceh, Banda Aceh: Lembaga hukom adat laot dan yayasan kehati, (2006)

[2] A. Jufri, "Revitalisasi Peran Lembaga Panglima Laot dalam Pengembangan Masyarakat Nelayan: Gampong Telaga Tujuh Kecamatan Langsa Timur Pemerintah Kota Langsa, Provinsi Nanggrau Aceh Darussalam," " Tesis pada Jurusan Profesional Pengembangan Masyarakat Sekolah Pasca Istitut Pertanian Bogor, Bogor, (2008)

[3] A. D. S. dkk, Sejarah Maritim Indonesia Menelusuri Jiwa Bahari Bangsa Indonesia Hingga Abad ke 17, Semarang: Jeda, (2013)

[4] I. Alfian, Perang Di Jalan Allah, Perang Aceh 1873-1912, Yogyakarta: Ombak, (2016)

[5] M. D. Majid, Catatan Pinggir Sejarah Aceh: Perdagangan, Diplomasi dan Perjuangan Rakyat, Jakarta: Yayasan Pustaka Obor Indonesia, (2014)

[6] K. V. Langen, Susunan Pemerintahan Aceh Semasa Kesultanan, Banda Aceh: Pusat Dokumentasi dan Informasi Aceh, (2002)

[7] R. Sufi, Pahlawan Nasional Sultan Iskandar Muda, Jakarta: Departemen Pendidikan Dan Kebudayaan Direktorat Jenderal Kebudayaan Direktorat Sejarah Dan Nilai Tradisional Proyek Inventarisasi Dan Dokumentasi Sejarah Nasional, (1995)

[8] Paul van't Veer, Perang Aceh (De Atjeh Oorlog)" penterjemah Grafitipers, Jakarta: Grafiti Pers, (1985)

[9] A. Reid, Asal Mula Konflik Aceh, Jakarta: Obor, (2005)

[10] C. S. Hurgronje, The Achenese" Traslated By the late A.W.S O’SULLIVAN Vol II, Leyden: Late E. J. Brill, (1906)

[11] de Sumatera Post, (1907)

[12] Sumatra Cauran, (1899)

[13] R. M. \&. Mujiburrahman, "Strategi Lembaga Adat Panglima Laot dalam Menyelesaikan Konflik (Sengketa) Masyarakat Nelayan di Kabupaten Pidie Provinsi Aceh," Jurnal Humaniora, Vols. vol.2, , no. No 2, pp. 110-117 (2018)

[14] M. Rachmad Munazir, "Menjaga Kelestarian Lingkungan Maritim Pesisir Yang Berkelanjutan Di Kabupaten Pidie Dengan Pendekatan Adat Laot," Jurnal Humaniora, vol. 1, no. 2, pp. 71-78 (2017)

[15] Mujiburrahman, "Perkembangan Panglima Laôt Dan Peranannya Dalam Kehidupan Masyarakat Nelayan Di Kecamatan Kembang Tanjong Kabupaten Pidie, Provinsi Aceh (1990- 2007)," Tesis Pada Jurusan Ilmu Sejarah Pasca Sarjana Universitas Diponegoro, Semarang, (2015) 
[16] Raihan, "Kepemimpinan Panglima Laot Dalam Menjaga Kedamaian Antar Nelayan Di Tpi Kecamatan Sawang Kabupaten Aceh Selatan," Al-IdarahJurnal Manajemen Dan Administrasi Islam. Al-Idarah, vol. 1, no. 1, p. 87, (2017)

[17] S. W. Rahayu, "Lembaga Penyelesaian Sengketa Adat Laut "Panglima Laôt" di Aceh sebagai Bentuk Pengembangan Alternaf Penyelesaian Sengketa dalam Sistem Hukum di Indonesia," Padjadjaran Jurnal Ilmu Hukum, vol. 1, no. 3, pp. 448-467, (2014)

[18] Mujiburrahman, "The Development and Roles of Panglima Laot in the Fishermen Community at Pidie, 1990-2007," Advanced Science Letters, vol. 23, no. 1, p. 10005-10007, (2017)

[19] S. Daud, Adat Meulaot: Adat menangkap ikan di laut, Banda Aceh: CV. Boebon Jaya, (2010)

[20] Perda No 7 Tahun 2000, (2000)

[21] Undang-Undang Republik Indonesia Nomor. 11 Tahun 2006., (2006) 